\title{
PHARMACOGNOSTIC AND PHYTOCHEMICAL SCREENING OF HELICTERES ISORA ROOTS
}

\author{
VEENA SHARMA*, URMILA CHAUDHARY
}

Department of Bioscience and Biotechnology, Banasthali University, Tonk, Rajasthan, India. Email: drvshs@gmail.com

Received: 11 April 2016, Revised and Accepted: 13 May 2016

\section{ABSTRACT}

Objective: Helicteres isora Linn. roots have been reported to use in microbial infection, diabetes, dysentery colic, scabies, wound healing, and gastropathy. The main objective of this study was preliminary phytochemical screening of various fractions of $H$. isora roots.

Methods: In this study, pharmacognostic and phytochemical investigations on the various fractions of $H$. isora roots were carried out with the standard procedures.

Results: The pharmacognostic analysis revealed moisture content (0.18\%), total ash (4\%), acid insoluble ash (1\%), and water soluble ash (1.5\%). The qualitative phytochemical screening revealed the presence of alkaloids, amino acids, proteins, carbohydrates, flavonoids, cardiac glycosides, saponin, steroids, terpenoids, and tannins.

Conclusion: $H$. isora roots are a rich source of various biological active constituents. $H$. isora may be further investigated for the isolation of bioactive compound that could be developed into drug for the treatment of various human diseases.

Keywords: Helicteres isora, Pharmacognostic, Phytochemical, Roots.

(C) 2016 The Authors. Published by Innovare Academic Sciences Pvt Ltd. This is an open access article under the CC BY license (http://creativecommons org/licenses/by/4. 0/) DOI: http://dx.doi.org/10.22159/ajpcr.2016.v9s2.12178

\section{INTRODUCTION}

Medicinal plants are the richest bio-resource of drugs of the traditional system of medicine, modern medicines, nutraceuticals, food supplements, and chemical entities for synthetic drugs [1] Plant based medicines initially dispensed in the form of a crude drugs such as tinctures, teas, poultices, powders and other herbal formulations, now serve as the basis of novel drug discovery [2], which are easily available, less expensive, safe and efficiently and rarely have side effects [3]. Medicinal plants are the good source of natural antioxidants. Helicteres isora, a medicinal plant was selected for the present research work.

H. isora Linn. (Sterculiaceae/Malvaceae), commonly known as "East India screw tree" in English and "Avartani" in Sanskrit, is a sub-deciduous herb or small tree, which occur, often gregariously, throughout India and in dry forests. Almost all parts of $H$. isora are used in a traditional medicinal system for curing various ailments. This plant contains dietary ascorbic acid, which plays a central role in the prevention of cancer [4]. Roots and bark of $H$. isora are expectorant, demulcentand are useful in colic, scabies, gastropathy, diabetes, diarrhea and dysentery [5]. H. isora possess various biological activities such as antidiabetic [6], hypolipidemic [7], antinociceptic [8], hepatoprotective [9], and cardiotonic [10] activities. Root juice of $H$. isora was claimed to be useful in fever, cough, asthma, stomach infections, and intestinal infections [11] and was also useful for healing of cuts, wounds [12], and scabies. Betulinic acid, daucosterol, sitosterol, isorin [13], cucurbitacin B, and isocucurbitacin B were isolated from the roots of $H$. isora [14]. Bark showed a significant hypoglycemic effect [15] and lowering effect of hepatic enzymes [16]. Fruits were used in alleviating griping and flatulence [17] and also showed antispasmodic effects [18].

This study deals with the roots of $H$. isora, which has been reported as a medicinal plant having various ethnobotanical uses, but not yet thoroughly explored. The first and important step is the characterization of various physicochemical parameters, powder characterization, and phytochemical screening of $H$. isora has been included here.

\section{METHODS}

Ferric chloride, n-nitrobenzene, and hydrochloric acid were purchased from HI-MEDIA (Mumbai). Ethyl acetate, Glacial Acetic acid, and Sulfuric acid were purchased from RANKEM (Gurgaon, Haryana). Phloroglucinol, sodium nitroprusside, petroleum ether and potassium iodide were purchased from MERCK (U.S.A). Millon's reagent, dragendorff reagent, and chloroform were procured from CDH (New Delhi). $\alpha$-Naphthol and pyridine were purchased from SRL (Gurgaon). Fehling solution A and B, lead acetate, and sodium hydroxide were procured from Qualigens, Thermo Fisher Scientific India Private Ltd. (Mumbai)). All other chemicals used in this study were of analytical grade.

Experimental plant: $\boldsymbol{H}$. isora

Roots of $H$. isora were collected from Shiwalik range of Uttar Pradesh. The plant was authenticated by Botanist of Krishi Vigyan Kendra, Banasthali University, Banasthali, Tonk district.

\section{Preparation of $\boldsymbol{H}$. isora fractions}

The $H$. isora roots were washed, shade dried, and subjected to size reduction to a coarse powder using an electric grinder. The powder was extracted with different solvents ranging from nonpolar to polar (petroleum ether, benzene, chloroform, ethyl acetate, ethanol, and distilled water) and hydroethanol in Soxhlet. These extracts were concentrated using rotary evaporator and stored at $4^{\circ} \mathrm{C}$ in airtight containers for further experimental studies, and the extractive values of all extracts were calculated in $\%$ yield.

\section{Determination of moisture content and total solid content} Root powder (1 g) was weighed and placed in petri-dish. Dried in oven at $105^{\circ} \mathrm{C}$ for $1 \mathrm{hr}$, then cooled in desiccators, loss in weight was recorded as moisture content [19].

Total solid content was determined by the following formula:

Total solid $(\%)=100-$ moisture content $(\%)$. 
Determination of extractive values of $\boldsymbol{H}$. isora root

\section{Determination of alcohol soluble extractive values}

Plant powder ( $5 \mathrm{~g}$ ) was weighed and transferred to a conical flask with $100 \mathrm{ml}$ ethyl alcohol (90\%). This mixture was kept aside for $24 \mathrm{hrs}$ with frequently shaking, then filtered and filtrate was collected, transferred to a weighed, thin porcelain dish. Evaporated to dryness on a water bath and dried completely in an oven at $90^{\circ} \mathrm{C}$ and kept in desiccators to cool. The percentage $\mathrm{w} / \mathrm{w}$ of extractive with reference to air dried drug was calculated [19].

\section{Determination of water soluble extractive value}

Plant powder (5 g) was mixed with $100 \mathrm{ml}$ chloroform:water (1:99). This mixture was allowed to stand for 24 hrs with frequently shaking, then the filtrate was collected, transferred to a weighed, thin porcelain dish. The filtrate was evaporated on a water bath, dried completely in an oven at $90^{\circ} \mathrm{C}$ and cooled in desiccators. The percentage $\mathrm{w} / \mathrm{w}$ of extractive with reference to air dried drug was calculated [19].

\section{Determination of ash content}

Residue of the crude drugs after incineration contains mostly inorganic salts (contain inorganic radicals like-phosphates, carbonates and silicates of sodium, potassium, magnesium, and calcium) known as ash [19].

\section{Total ash content}

Carbon and organic matter present in the plant is converted to ash at temperature $450^{\circ} \mathrm{C}$. It contains mostly carbonates, phosphates, silicates, and silica. The powder is incinerated by gradually increasing the heat in a muffle furnace up to $450^{\circ} \mathrm{C}$ until complete burn and having constant weight. After complete incineration, it was kept in a desecrator. The total ash content was calculated in terms of percentage.

\section{Calculation:}

Total ash value of the sample $=100(\mathrm{Z}-\mathrm{X}) / \mathrm{Y}$

$\mathrm{X}=$ Weight of the empty dish, $\mathrm{Y}=$ Weight of the drug taken, $\mathrm{Z}=$ weight of dish+ash (after complete incineration).

\section{Acid insoluble ash values}

Proceed as per the steps mentioned in the procedure for the determination of total ash value of a crude drug. Dilute hydrochloric acid ( $25 \mathrm{ml}$ ) mixed with total ash and boil on burner for 5 minutes. Filter through the ash-less filter paper and wash the residue twice with hot water. Ash residue with filter paper in crucible put into the incinerator for complete incineration until complete carbon has been removed. Cool in desiccator, and after weighing the residue, acid insoluble ash values of the plant was calculated.

\section{Water soluble ash values}

Proceed as per the steps mentioned in the procedure for the determination of total ash value of a crude drug. Distilled water $(25 \mathrm{ml})$ mixed with total ash and boiled on burner for 5 minutes. Filter through the ash-less filter paper and washed the residue twice with hot water. Ash residue with filter paper in crucible put into the incinerator for complete incineration until constant weight obtained. Cool in desiccator, and after weighing the residue, water soluble ash values of plant was calculated.

\section{Fluorescent analysis of $\boldsymbol{H}$. isora roots}

$H$. isora root powder was taken into clean and dried Petri-dishes. To each petri-dish 3-5 ml of various solvents like methanol, ethanol, water, glacial acetic acid, chloroform, sulfuric acid, hydrochloric acid, nitric acid, and sodium hydroxide, nitrogen hydroxide, potassium hydroxide, ferric chloride, and iodine solution were added separately. Then, all the Petri-dishes were allowed to stand for few minutes (20-25 minutes) after the proper mixing. After that, all the plates were observed under the ultraviolet (UV) and visible light and colors were recorded for further comparison [20].

\section{Phytochemical screening}

Qualitative phytochemical analysis of $H$. isora root extracts was carried out using standard procedures.

\section{Test for alkaloids [21]}

Dragendorff's test

Alkaloids (present in plant extract) give reddish brown precipitate with Dragendorff's reagent (potassium bismuth iodide solution).

\section{Mayer's test}

Alkaloids (present in plant extract) give cream color precipitate with Mayer's reagent (potassium mercuric iodine solution).

\section{Hager's test}

Alkaloids (present in plant extract) give yellow precipitate with Hager's reagent (saturated solution of picric acid)

\section{Wagner's test}

Alkaloids (present in plant extract) give reddish brown precipitate with Wagner's reagent (Iodine-potassium iodide solution)

\section{Tannic acid test}

Alkaloids give buff color precipitate with tannic acid solution.

\section{Test for amino acids [21]}

Millon's test

To the plant extract added Millon's reagent (about $2 \mathrm{ml}$ ), the appearance of white precipitate indicates the presence of amino acids.

\section{Ninhydrine test}

To the plant extract (sample) ninhydrin solution was added, boiled and then the appearance of violet color indicates presence of amino acid.

\section{Test for proteins [22]}

\section{Biuret reaction}

To alkaline solution of protein $(2 \mathrm{ml})$, a dilute solution of copper sulfate is added. A red or violet color is formed with peptides containing at least two peptide linkages. A dipeptide does not respond this test.

\section{Xanthoproteic reaction}

Protein usually forms a yellow color on warming with concentrated nitric acid. This color becomes orange when the solution is made alkaline. The color is due to nitration of aromatic ring containing amino acids like phenylalanine and tyrosine.

\section{Ninhydrin test}

To the plant extract (sample), alcoholic solution of ninhydrin was added and boiled; the appearance of red to violet color indicates the presence of amino acid.

\section{Nitroprusside test}

Protein containing sulfur atom form red color with nitroprusside solution.

\section{Lead sulfide test}

Alkaline solution of sulfur containing protein, on addition of lead acetate, produces a black precipitate.

\section{Test for carbohydrates}

\section{Molisch's test}

To the test sample (2-3 ml) added few drops of alcoholic alpha-naphthol solution, shake well and then added few drops of concentrated $\mathrm{H}_{2} \mathrm{SO}_{4}$ 
from side of the test tube, the appearance of purple to violet color ring at the junction indicate the presence of carbohydrates [21,23].

\section{Test for monosaccharide}

Barfoed's test

An equal volume of Barfoed's reagent and test solution mixed well and heat for 1-2 minutes. in a boiling water bath, then cool, appearance of red precipitate indicate the presence of monosaccharide in plant extract [23].

\section{Test for reducing sugar}

\section{Fehling's test}

Mix Fehling's solution A (1 ml) and Fehling's solution B (1 ml), boiled for 1 minute added equal volume of test sample. Heat in a boiling water bath for 5-10 minutes appearance of first a yellow, then brick red precipitate indicate the presence of reducing sugar in plant extract [23].

\section{Benedict's test}

Mix equal volume of Benedict's reagent and test sample in test tube, heat in a boiling water bath for 5 minutes. Solution appears green, yellow or red depending on amount of reducing sugar present in plant extract [23].

\section{Test for pentose sugar \\ Pholoroglucinol test}

Mix equal amount of test sample and hydrochloric acid, added a crystal of pholoroglucinol. Observation of red color showed the presence of pentose sugar in plant extracts [23]

\section{Test for hexose sugar [23]}

Selwinoff test (for ketohexose like fructose)

Mix Selwinoff's reagent $(3 \mathrm{ml})$ and test solution $(1 \mathrm{ml})$ and heat in boiling water bath for 1-2 minutes. Red color is formed.

\section{Tollen's phloroglucinol test for galactose}

Mix concentrated hydrochloric acid ( $2.5 \mathrm{ml}$ ) and $0.5 \%$ phloroglucinol (4 ml) and added 1-2 $\mathrm{ml}$ test sample. Yellow to red color appears.

\section{Cobalt-chloride test}

Mix test sample $(3 \mathrm{ml})$ with cobalt chloride $(2 \mathrm{ml})$, boiled and cooled, then added few drops of sodium hydroxide solution. Solution appears greenish blue (glucose) or purplish (fructose) or upper layer greenish blue and lower layer purplish (mixture of glucose and fructose).

\section{Test for flavonoids}

\section{Shinoda test}

To the test, solution added few magnesium turnings and dropwise concentrated hydrochloric acid, pink scarlet, crimson red and occasionally green to blue color appears after few minutes [21].

\section{Lead acetate test}

The extracts were treated with lead acetate solution. The formation of yellow precipitate confirmed the presence of flavonoids [23].

\section{Alkaline reagent test}

To the test solution, added few drops of nitrogen hydroxide solution formation of intense yellow color, which turns to colorless on the addition of few drops of dilute acid, indicates the presence of flavonoids [21].

\section{Zinc hydrochloride test}

To the test solution, added a mixture of zinc dust and concentrated hydrochloric acid. It gives red color after few minute [21]

\section{Vanillin hydrochloric acid test}

To the alcoholic solution of a flavonoid (plant extract), vanillinhydrochloric reagent is added. A pink color is formed [22].

\section{Test for fats and fixed oil}

\section{Copper sulfate test}

Treat test sample (5 drops) with $1 \%$ copper sulfate solution (1 ml), then added $10 \%$ sodium hydroxide solution. A clear blue solution is obtained which show glycerin is present in the sample. The cupric hydroxide formed in the reaction does not precipitate out as it is soluble in glycerin [21].

\section{Paper test}

Filter paper gets permanently stained with oils [23].

\section{Test for cardiac glycosides}

Keller-Killiani test (test for deoxysugars)

To the plant extract $(2 \mathrm{ml}$ ), glacial acetic acid, one drop of $5 \%$ ferric chloride and concentrated sulfuric acid was added. Reddish brown color obtained at junction of the two liquid layers and upper layer appear blue-green, indicate the presence of cardiac glycosides [23]

\section{Baljet test}

The plant extract solution was treated with picric acid or sodium picrate, the appearance of orange color indicates the presence of cardiac glycosides [21].

\section{Legal's test}

The plant extract solution was treated with pyridine $(1 \mathrm{ml})$ and added sodium nitroprusside solution (1 ml), the appearance of pink to red color indicates the presence of cardiac glycosides [23].

\section{Test for anthraquinone glycosides}

Borntrager's test

To the plant extracts ( $3 \mathrm{ml}$ ), added dilute sulfuric acid, boiled and filtered. To cold filtrate, added equal volume of benzene or chloroform, shake well and separate the organic solvent. Added ammonia, ammoniacal layer turns pink or red showed the presence of anthraquinone glycosides in the plant extract [23].

\section{Test for saponin glycosides}

Froth formation test

Place $2 \mathrm{ml}$ plant extract with water in a test tube, shake well, stable froth (foam) is formed showed the presence of saponin glycosides in the plant sample [21].

\section{Test for cynogenic glycosides}

Guignard reaction or sodium-picrate test: Soak a filter paper strip first in $10 \%$ picric acid, then in $10 \%$ sodium carbonate and dry it. In a conical flask place moistened powder drug (plant extract), cork it and place the above filter paper strip in the strip in cork. The filter paper turns brick red or maroon showed the presence of cynogenic glycosides in the plant sample [23].

\section{Test for steroids and terpenoids}

\section{Salkowski test}

Plant extracts (sample) were treated with few drops of concentrated sulfuric acid red color at lower layer indicates the presence of steroids and formation of yellow colored lower layer indicates the presence of triterpenoids [21].

\section{Liebermann-Burchard test}

Plant extracts were treated with few drops of acetic anhydride, boiled and cooled. Then added concentrated sulfuric acid from the side wall of the test tube, brown ring formed at the junction of two layers and upper 
layer turns green which shows the presence of steroids and formation of deep red color indicates the presence of triterpenoids [21]

\section{Zimmermann test}

A mixture of plant extract and m-dinitrobenzene in the presence of an alkali on heating gives violet color, which faded after dilution for 3-oxo steroids and triterpenes [22].

\section{Tests for tannins and phenols}

\section{Ferric chloride test}

Plant extract was treated with ferric chloride solution, blue color appears if hydrolysable tannins were present and green color appears if condensed tannins were present [21].

\section{Gelatin test}

To the plant extract, $1 \%$ gelatin solution containing $10 \%$ sodium chloride was added. Formation of precipitate indicates the presence of tannins or phenols [21].

\section{Test for chlorogenic acid (ammonia test)}

Plant extracts were treated with aqueous ammonia and exposed to air gradually, green color was developed [21].

\section{Lead acetate test}

The extracts were treated with lead acetate solution. The formation of white precipitate confirmed the presence of phenols and tannins [23].

\section{Diluted nitric acid test}

The extracts were treated with diluted nitric acid solution after that the appearance of reddish to brown color confirmed the presence of phenols and tannins [23].

\section{Silver nitrate $\left(\mathrm{AgNO}_{3}\right)$ test}

The extracts were treated with one drop of ammonium hydroxide and excess $10 \%$ silver nitrate solution, and heat for 20 minutes in boiling water bath. White precipitate observed, and then dark silver mirror deposits on wall of test tube indicate the presence of phenols and tannins [23].

\section{RESULTS}

Yield of various extracts of $H$. isora in \% (w/w)

Yield of the various extracts from the plant was mainly dependent on the type of solvent used in the extraction procedure. The percentage yield of the six extracts (petroleum ether, benzene, chloroform, ethyl acetate, ethanol, and distilled water) of $H$. isora roots are summarized in Table 1. The $\%$ yield was high in aqueous extract $(19.46 \%)$ whereas, petroleum ether extract had showed minimum \% yield as $0.5 \%$. Primarily water was used as a solvent by traditional healers or practitioners.

\section{Pharmacognostic evaluation of various extracts of $\boldsymbol{H}$. isora}

Ash content determination was a very important parameter for the authentication and purity of plant sample. Total ash, water soluble, and acid insoluble ash was found to be $4 \%, 1.5 \%$, and $1 \%$, respectively. Total ash includes both non-physiological ash (residue of extra matter that adhering to the plant surface) and physiological ash (plant tissue itself). Acid soluble ash measures the amount of silica, sand and siliceous earth present with plant material [24]. The alcohol and water soluble extractive values determination also play an important role in crud drug evolution. More extractive values indicate less adulteration and correct processing with more purity of sample. Alcohol soluble extractive value $(12.80 \%)$ proved to be less than water soluble extractive value $(18.93 \%)$. These indicate that $H$. isora roots constituents were more extracted with water due to more solubility in comparison to alcohol. Deterioration of drug was affected by various factors and most important was moisture content. Moisture content was inversely proportional to the stability of drugs. Roots of $H$. isora showed $0.18 \%$ moisture content, so it is more stable (Table 2).

\section{Fluorescence analysis of $\boldsymbol{H}$. isora root powder}

The observed results of $H$. isora roots with various solvents and chemical reagents are summarized in Table 3 . The root powder of $H$. isora showed the presence of florescent compound.

\section{Qualitative phytochemical screening}

Various phytoconstituents were tested in various extracts of $H$. isora roots with standard procedures and results are summarized in Table 4. According to the observed results, aqueous extract of $H$. isora possess

Table 1: Percentage yield of various extracts of Helicteres isora roots

\begin{tabular}{lll}
\hline S. No & Extracts & \% Yield \\
\hline 1 & PEHI & $0.5 \pm 0.021$ \\
2 & BEHI & $0.75 \pm 0.042$ \\
3 & CEHI & $1.28 \pm 0.205$ \\
4 & EAEHI & $1.62 \pm 0.926$ \\
5 & EEHI & $4.88 \pm 0.601$ \\
6 & AEHI & $19.46 \pm 1.001$ \\
7 & HEEHI & $11.13 \pm 0.902$ \\
\hline
\end{tabular}

PEHI: Petroleum ether extract of Helicteres isora, BEHI: Benzene extract of Helicteres isora, CEHI: Chloroform extract of Helicteres isora, EAEHI: Ethyl acetate extract of Helicteres isora, EEHI: Ethanolic extract of Helicteres isora AEHI: Aqueous extract of Helicteres isora, HEEHI: Hydroethanolic extract of Helicteres isora

Table 2: Data for various pharmacognostic parameters of Helicteres isora roots

\begin{tabular}{lll}
\hline S. No & Parameters & $\mathbf{\%}(\mathbf{w} / \mathbf{w})$ \\
\hline 1 & Moisture content & 0.18 \\
2 & Total solid content & 99.82 \\
3 & Alcohol soluble extractive value & 12.80 \\
4 & Water soluble extractive value & 18.93 \\
5 & Total ash value & 4.00 \\
6 & Acid insoluble ash value & 1.00 \\
7 & Water soluble ash value & 1.50 \\
\hline
\end{tabular}

Table 3: Fluorescence analysis of Helicteres isora root powder

\begin{tabular}{|c|c|c|c|}
\hline S. No & Plant sample & UV light & Day light \\
\hline 1 & Powder as such & Light brown & Light brown \\
\hline 2 & Powder+concentrated $\mathrm{Hcl}$ & Light brown & $\begin{array}{l}\text { Yellowish brown/ } \\
\text { yellowish cream }\end{array}$ \\
\hline 3 & $\begin{array}{l}\text { Powder+Concentrated } \\
\mathrm{HNO}_{3}\end{array}$ & Light yellow & $\begin{array}{l}\text { Sunset yellow/ } \\
\text { orange }\end{array}$ \\
\hline 4 & $\begin{array}{l}\text { Powder+Concentrated } \\
\mathrm{H}_{2} \mathrm{SO}_{4}\end{array}$ & Dark red & $\begin{array}{l}\text { Blackish } \\
\text { muhroon }\end{array}$ \\
\hline 5 & Powder+glacial acetic acid & White & Light yellow \\
\hline 6 & Powder $+5 \% \mathrm{NaOH}$ & $\begin{array}{l}\text { Yellowish } \\
\text { orange }\end{array}$ & Light yellow \\
\hline 7 & Powder $+5 \% \mathrm{KOH}$ & Sunset yellow & Light yellow \\
\hline 8 & $\begin{array}{l}\text { Powder }+1 \mathrm{~N} \mathrm{NaOH} \text { in } \\
\text { methanol }\end{array}$ & Light purple & Light milky green \\
\hline 9 & $\begin{array}{l}\text { Powder }+1 \mathrm{~N} \mathrm{NaOH} \text { in } \\
\text { water }\end{array}$ & Brown & Reddish brown \\
\hline 10 & Powder+50\% $\mathrm{Hcl}$ & Light purple & Light brown \\
\hline 11 & Powder $+50 \% \mathrm{HNO}_{3}$ & Light yellow & Yellowish orange \\
\hline 12 & Powder+chloroform & Creamy white & Muddy \\
\hline 13 & Powder+ethanol & Milky white & Milky white \\
\hline 14 & $\begin{array}{l}\text { Powder }+5 \% \text { ferric } \\
\text { chloride solution }\end{array}$ & Dark green & Yellowish green \\
\hline 15 & $\begin{array}{l}\text { Powder }+5 \% \text { Iodine } \\
\text { solution }\end{array}$ & Dark brown & $\begin{array}{l}\text { Dark reddish } \\
\text { brown }\end{array}$ \\
\hline
\end{tabular}


Table 4: Phytochemical screening of various extracts of Helicteres isora root

\begin{tabular}{|c|c|c|c|c|c|c|c|c|}
\hline Compounds & Test name & PEHI & BEHI & CEHI & EAEHI & EEHI & AEHI & HEEHI \\
\hline \multirow[t]{5}{*}{ Alkaloids } & Dragendorff's test & + & - & - & - & + & - & + \\
\hline & Mayer's test & - & - & - & - & - & + & - \\
\hline & Hager's test & - & - & - & - & - & - & - \\
\hline & Wagner's test & - & - & + & - & - & - & - \\
\hline & Tannic test & - & + & - & + & + & - & - \\
\hline \multirow[t]{2}{*}{ Amino acids } & Millon's test & - & - & - & - & - & - & - \\
\hline & Ninhydrin test & - & - & - & - & + & + & + \\
\hline \multirow{4}{*}{ Proteins } & Xanthroprotective reaction & + & - & + & + & + & + & + \\
\hline & Ninhydrin test & - & - & - & - & + & - & + \\
\hline & Nitroprusside test & - & - & - & - & - & - & - \\
\hline & Lead sulfide test & - & - & - & - & - & - & - \\
\hline \multirow[t]{10}{*}{ Carbohydrates } & Molish's test & - & - & - & - & - & - & - \\
\hline & Test for reducing sugar & & & & & & & \\
\hline & Fehling's test & - & - & + & - & - & - & - \\
\hline & Benedict test & - & + & + & - & + & + & + \\
\hline & Test for pentose sugar & & & & & & & \\
\hline & Pholoroglucinol test & + & + & + & + & + & + & + \\
\hline & Test for hexose sugar & & & & & & & \\
\hline & Selwinoff test (for ketohexose like fructose) & - & - & - & - & - & - & - \\
\hline & Tollen's phloroglucinol test for galactose & + & + & + & + & + & + & + \\
\hline & Cobalt-chloride test & - & - & - & - & - & + & + \\
\hline \multirow[t]{5}{*}{ Flavonoids } & Shinoda test & - & - & - & - & - & - & - \\
\hline & Lead acetate test & - & - & + & - & - & + & + \\
\hline & Alkaline reagent test & + & - & - & + & + & - & - \\
\hline & Zinc $\mathrm{HCl}$ test & - & + & - & - & - & + & - \\
\hline & Vanillin $\mathrm{HCl}$ test & - & - & - & - & - & - & - \\
\hline \multirow[t]{2}{*}{ Fat and fixed oils } & Copper sulfate test & + & + & + & - & + & + & + \\
\hline & Paper test & - & - & - & - & - & + & + \\
\hline \multirow[t]{3}{*}{ Cadiac glycosides } & Keller-killiani test (for deoxysugars) & - & - & - & - & + & - & + \\
\hline & Baljet test & - & + & + & - & + & + & + \\
\hline & Legal's test (for anthraquinone glycosides) & - & - & + & - & - & - & - \\
\hline Cynogenic glycosides & Guignard reaction or sodium picrate test & - & - & - & - & - & - & - \\
\hline \multirow[t]{4}{*}{ Steroids and terpenoids } & Salkowski reaction (steroids) & + & + & + & + & + & + & + \\
\hline & Salkowski reaction (terpenoids) & + & + & + & + & - & - & - \\
\hline & Zimmermann test & - & - & - & - & - & - & + \\
\hline & Liebermann-Burchard reaction & - & - & - & + & + & + & - \\
\hline \multirow[t]{5}{*}{ Tannins } & $\mathrm{FeCl}_{3}$ test & - & - & - & - & + & + & + \\
\hline & Ammonia test (for chlorogenic acid) & - & - & - & - & - & - & - \\
\hline & Lead acetate test & + & + & - & + & + & + & + \\
\hline & Dilute $\mathrm{HNO}_{3}$ test & - & + & + & - & + & + & + \\
\hline & $\mathrm{AgNO}_{3}$ test & - & - & - & - & + & + & - \\
\hline
\end{tabular}

PEHI: Petroleum ether extract of Helicteres isora, BEHI: Benzene extract of Helicteres isora, CEHI: Chloroform extract of Helicteres isora, EAEHI: Ethyl acetate extract of Helicteres isora, EEHI: Ethanolic extract of Helicteres isora, AEHI: Aqueous extract of Helicteres isora, HEEHI: Hydroethanolic extract of Helicteres isora

all the constituents. Tannins, pentose sugar, hexose sugar, steroids, terpenoids, flavonoids, and alkaloids were present in all extracts. Proteins were present in all extracts except benzene extract. All extracts possess fats and fixed oil except ethyl acetate extract of $\mathrm{H}$. isora. Only ethanol, aqueous and hydroethanolic extracts show the presence of amino acids.

\section{DISCUSSION}

This study deals with the roots of $H$. isora, a medicinal herb. According to this study, water extract of this plant parts was found to be certainly much better than other extracts in the \% yield. This may be due to the better solubility of the active compound in polar solvents [25]. The results also showed the presence of various chemical constituents that showed florescence phenomena in the of $H$. isora root powder. Some constituents like alkaloids (berberine) showed florescence in the UV light due to the production of derivatives using different chemical reagents, but normally do not florescence in day light. Many substances only show florescence when treated with a different reagent, but they themselves are not florescent. Hence, some plant drugs are often determined qualitatively with florescent analysis and this is an important parameter of pharmacognostic evaluation [26]. This florescent method is more sensitive for the analysis of pharmaceutical samples [27]. To understand the nature of florescence emission from the sample with different reagents, the phytochemical analysis of the sample was compared. The comparative analysis clearly proved a correlation between the florescence behavior and compounds present in the sample. Flavones are light yellow in aqueous solution under UV light turns to bright yellow in alkaline solution. Terpenoids (sapogenins) exhibit yellow green florescence under UV light [28]. Least florescence was shown by fixed oil and fats but waxes more strongly florescence under UV light $[27,29]$

Phytochemical screening of plant sample is very important parameter because it provides wide information for the therapeutic agent discovery and finds the new rich source of economical compounds like tannins, gums, flavonoids and saponin [30]. Alkaloids present in plant sample are responsible for antitumor, antimicrobial and antiinflammatory properties [31]. Due to the presence of flavonoids and tannins plant sample possess antibacterial, antifungal, antiparasitic, astringent, 
antioxidant, antimicrobial, anthelmintic activities, and also regenerate the beta cells that are damaged in the diabetic rats [32-35]. Tannins are also used as healing agent in burns, leucorrhea, inflammation, gonorrhea, pile, and antidote [36,37]. The presence of saponin in the plant sample conform the medicinal properties of the plant. Saponins are responsible for the inflammatory and hypocholesterolemic activity of the medicinal plant. Plant acts as an antiseptic, stimulant, anthelmintic, diuretic and counter-irritant due to the presence of terpenoids [38]. Flavonoids, sterols, phenolic acids, terpenoids, glycosides, and alkaloids are responsible for the antidiabetic activity of medicinal plant $[36,38,39]$. Therefore, the roots of $H$. isora are important it possesses various biological activities and medicinal properties due to the presence of various phytoconstituents.

\section{CONCLUSION}

In conclusion, the phytochemical analysis shows the presence of flavonoids, tannins, saponin, alkaloids, amino acids, proteins, carbohydrates, steroids, terpenoids, and fats in the $H$. isora roots that support the traditional use of the plant in the management of various ailments. Information regarding chemical constituents and physicochemical characteristics of $H$. isora roots would be useful for standardization and formulation of herbal drugs for the treatment of various diseases.

\section{REFERENCES}

1. Ncube NS, Afolayan AJ, Okoh AI. Assessment techniques of antimicrobial properties of natural compounds of plant origin: Current methods and future trends. Afr J Biotechnol 2008;7(12):1797-806.

2. Geysen HM, Schoenen F, Wagner D, Wagner R. Combinatorial compound libraries for drug discovery: An ongoing challenge. Nat Rev Drug Discov 2003;2(3):222-30.

3. Yadav RN, Agarwala M. Phytochemical analysis of some medicinal plants. J Phytol 2011;3(12):10-4.

4. Sabale PM, Grampurohit ND, Banerjee SK, Gaikwad DD, Gadhave MV. Recent advances on the phytochemical and pharmacological profile of plant Helicteres isora Linn. Int Res J Pharm 2012;3(4):14-7.

5. Kirtikar KR, Basu BD. Indian Medicinal Plants. Vol. 1. Dehradun, India: International Book Distributions; 1995. p. 371-2.

6. Chakrabarti R, Reeba K, Vikramadithya RM, Sharma VM, Jagadheshan N, Rao YN, et al. Antidiabetic and hypolipidemic activity of Helicteres isora in animal models. J Ethnopharmacol 2002;81:343-9.

7. Kumar G, Murugesan AG. Hypolipidaemic activity of Helicteres isora L. bark extracts in streptozotocin induced diabetic rats. J Ethnopharmacol 2008;116:161-6.

8. Venkatesh S, Laxmi KS, Reddy BM, Ramesh M. Antinociceptive activity of Helicteres isora. Fitoterapia 2007;78:146-8.

9. Dhevi R, Gayathri K, Mohamed MS, Subashini U, Dubey GP, Victor GR, et al. A preliminary biochemical screening of Helicteres isora $\mathrm{L}$. Stem bark in carbon tetrachloride induced toxicity in rats. Bulg J Vet Med 2008;11(4):235-42.

10. Dama GY, Taare HL, Gore MS, Shende VS, Deore SR, Khandagale ST, et al. Comparative cardiotonic activity of Helicteres isora with digoxin on isolated frog heart. Int J Precis Res 2011;2(2):81-6.

11. Kirtikar KR, Basu BD. Indian Medicinal Plants. $2^{\text {nd }}$ ed. Allahabad: Bishan Singh Mahendra Pal Singh; 1991. p. 371-2.

12. Nagaraju N, Rao KN. A survey of plant crude drugs of Rayalaseema, Andhra Pradesh, India. J Ethnopharmacol 1990;29(2):137-58.

13. Qu WH, Li JG, Wang MS. Chemical studies on the Helicteres isora. Zhongguo Yaoke Daxue Xuebao 1991;22(4):203-6.

14. Bean MF, Antoun M, Abramson D, Chang CJ, McLaughlin JL, Cassady JM. Cucurbitacin B and isocucurbitacin B: Cytotoxic components of Helicteres isora. J Nat Prod 1985;48:500.

15. Kumar G, Banu GS, Murugesan AG, Pandian MR. Hypoglycaemic effect of Helicteres isora bark extract in rats. J Ethnopharmacol 2006;107:304-7.

16. Kumar G, Murugesan AG, Rajasekara Pandian M. Effect of Helicteres isora bark extract on blood glucose and hepatic enzymes in experimental diabetes. Pharmazie 2006;61(4):353-5.

17. Chopra RN, Nayar SL, Chopra IC. Glossary of Indian Medicinal Plants (Including the Supplement). New Delhi, India: Council of Scientific and Industrial Research; 1986

18. Pohocha N, Grampurohit ND. Antispasmodic activity of the fruits of Helicteres isora Linn. Phytother Res 2001;15(1):49-52.

19. Joseph L, George M. Pharmacognostic profile of Geranium ocellatum leaves. Int J Med Arom Plants 2011;1(3):351-4.

20. Chase CR, Pratt RJ. Fluorescence of powdered vegetables drugs. Indian J Exp Biol 1949;33(6):428-32.

21. Kokate CK, Purohit AP, Gokhale SB. Pharmacology: Pathway to screen phytochemical nature of natural drugs. Pune, India: Nirali Prakashan; 2008. p. A.1-A.6.

22. Siddiqui AA, Ali M. Practical Pharmaceutical Chemistry: Identification Test of Organic Drugs. New Delhi: CBS Publishers and Distributers; 2008. p. 126-32.

23. Khandelwal KR. Practical Pharmacology Techniques and Experiments. Pune, India: Nirali Parkashan; 2006. p. 15-163.

24. Kokate CK, Purohit AP, Gokhale SB. Pharmacognosy. $38^{\text {th }}$ ed. Pune, India: Nirali Prakashan; 2007.

25. Tullanithi KM, Band S, Gnanendra TS. Preliminary phytochemical analysis and antimicrobial activity of Achyranthes aspera Linn. Int $\mathrm{J}$ Biol Technol 2010;1(3):35-8.

26. Ansari SH. Essentials of Pharmacognosy. $1^{\text {st }}$ ed. New Delhi: Birla Publications Pvt., Ltd.; 2006.

27. Pimenta AM, Montenegro MC, Araújo AN, Calatayud JM. Application of sequential injection analysis to pharmaceutical analysis. J Pharm Biomed Anal 2006;40:16-34.

28. Oliver-Bever B. Medicinal Plants in Tropical West Africa. London: Cambridge University Press; 1986.

29. Price KR, Johnson LI, Ferewick H. The chemical and biological significant of saponins in food and feeding staffs. CRC Critical Rev Food Sci Nut 1987;26:127-35.

30. Akrout A, El Jani H, Zammouri T, Mighri H, Neffati M. Phytochemical screening and mineral contents of annual plants growing wild in the Southern of Tunisia. J Phytol 2010;2(1):34-40.

31. Castilhos TS, Giordani RB, Henriques AT, Menezes FS, Zuanazzi JA. In vitro evaluation of the antioxidant, antiinflammatory and antimicrobial activities of the montanine alkaloid. Braz J Pharmacogn 2007; 17:209-14.

32. Ho KY, Tsai CC, Huang JS, Chen CP, Lin TC, Lin CC. Antimicrobial activity of tannin components from Vaccinium vitis-idaea L. J Pharm Pharmacol 2001;53(2):187-91.

33. Sen G, Mandal S, Saha Roy S, Mukhopadhyay S, Biswas T. Therapeutic use of quercetin in the control of infection and anemia associated with visceral leishmaniasis. Free Radic Biol Med 2005;38(9):1257-64.

34. Killedar SG, More HN. Estimation of tannins in different parts of Memecylon umbellatum Burm. J Pharm Res 2010;3(3):554-6.

35. Singh S, Mehta A, John J, Mehta P. Anthelmintic potential of Andrographis paniculata, Cajanus cajan and Silybum marianum. J Pharmacogn 2010;2:71-3.

36. Handa SS, Kapoor VK, editors. Pharmacognosy. New Delhi: Vallabah Prakashan Publications; 1992. p. 51.

37. Ali M. Text Book of Pharmacognosy. New Delhi: CBS Publishers and Distributors; 1994. p. 405.

38. Gokhale SG, Kokate CK, Purohit AP. A Text Book of Pharmacognosy. Pune: Nirali Prakashan; 2003.

39. Loew D, Kaszkin M. Approaching the problem of bioequivalence of herbal medicinal products. Phytother Res 2002;16(8):705-11. 